\title{
Penerapan Metode Tebak Kata Dalam Meningkatkan Pemahaman Siswa tentang Peranan Indonesia Dalam Era Globalisasi di SD Negeri 025 Indra Puri
}

\author{
SUPINGI \\ Dinas Pendidikan Kabupaten Kampar \\ SD Negeri 025 Indra Puri \\ E-mail : supingi_025@gmail.com
}

\begin{abstract}
Lessons for elementary school students are emphasized how to provide knowledge about all things. This knowledge is more directed at them to get to know the real conditions. Citizenship education lessons form the basis for elementary school students to get to know the Indonesian people and as citizens and also related to the role of the Indonesian people in the globalization arena. Through classroom action research, it will apply the word guessing method to increase the increase of knowledge along with their understanding in seeing the subject matter of the role of Indonesia in the era of globalization. The 025 elementary school students, especially class VI, applied this method and the data collected through observation and questionnaires were analyzed descriptively. The results showed that the application of the word guessing method applied to elementary school students in class VI was able to increase their knowledge and understanding of the role of the Indonesian people in the era of globalization.
\end{abstract}

Keywords: Guess Word Method, Globalization

Peran guru sebagai pengelola proses belajar mengajar, mengembangkan bahan pelajaran dengan baik, dan meningkatkan kemampuan murid untuk menyimak pelajaran dan menguasai tujuan-tujuan pendidikan yang harus mereka capai. Untuk itu dibutuhkan peranan seorang guru, secara umum guru memiliki pengaruh besar dalam proses pembelajaran. Peran guru dalam pembelajaran salah satunya adalah membangkitkan minat belajar murid. Guru dalam hal ini mempunyai peranan dalam menumbuhkan dan mengembangkan minat belajar murid.

Proses belajar mengajar guru mempunyai peranan pokok, seperti yang dikemukakan Moh Uzer Usman (2005) "Dalam menciptakan kondisi belajar mengajar yang egfektif guru harus melibatkan murid secara aktif dan guru harus mampu menarik minat dan perhatian murid ". Untuk mewujudkan tujuan pembelajaran tersebut, guru diharap mempunyai pengetahuan ketrampilan untuk menumbuhkan minat murid dalam proses belajar mengajar. $\begin{array}{cccc}\text { Peranan } & \text { guru } & \text { PKN } & \text { dalam } \\ \text { meningkatkan } & \text { prestasi } & \text { belajar } & \text { murid }\end{array}$ dilakukan saat proses belajar mengajar, guru dituntut mampu mengelola proses belajar mengajar yang memberikan rangsangan kepada murid sehingga ia mau belajar. "Guru harus dapat menciptakan kondisi belajar yang efektif yaitu dengan : a) melibatkan murid secara aktif, b) menarik minat dan perhatian murid, c) membangkitkan motivasi murid, d) peragaan dalam pengajaran" (Moh Uzer Usman, 2001).

Mengajar adalah membimbing kegiatan belajar murid sehingga ia mau belajar. Dengan demikian aktivitas murid sangat diperlukan dalam kegiatan belajar mengajar sehingga muridlah yang seharusnya banyak aktif dalam belajar. Selain itu dalam penggunaan metode dan media pengajaran guru dituntut menggunakan metode dan media belajar yang bervariasi. Hal ini bertujuan agar murid tidak merasa bosan dalam belajar.

Dalam proses belajar mengajar memiliki dua subjek utama yaitu guru dan 
murid. Apabila salah satu dari objek tersebut tidak ada maka tidak akan terjadi proses belajar mengajar. Guru bertugas membantu murid untuk mencapai tujuan pendidikan tersebut. Oleh karena itu sebagai seorang guru harus melaksanakan apa yang menjadi tugas dan peranannya dengan baik.

Tugas utama guru adalah mengajar dan juga mempunyai peranan yang komplek dalam proses belajar mengajar yaitu sebagai : informator, organisator, motivator, direktur, inisiatur, tranmiter, fasilitator, mediator, dan evaluator. Guru harus mampu membimbing murid agar menjadi sumber daya manusia yang berkualitas dan membantu mengembangkan potensi diri dan juga kemampuankemampuan yang diperoleh dari hasil belajar. Dengan berbagai peranannya tersebut guru diharapkan mampu meningkatkan minat belajar murid.

Permasalahan yang dihadapi guru mata pelajaran pendidikan kewarganegaraan di SD N 025 Indra Puri kelas VI PKN II semester genap adalah pada sub materi peranan politik luar negeri Indonesia dalam era globalisasi, sesuai dengan kompetensi dasarnya menjelaskan berbagai peranan politik luar negeri Indonesia dalam era globalisasi. Dari data tersebut di atas jelas dapat diketahui ketuntasan murid yang rendah. Sedangkan sisanya masih belum tuntas dan persoalan ini menjadi masalah karena standar pencapaian ketuntasan yang diharapkan adalah 80 dari murid di kelas. Selama ini metode pembelajaran yang digunakan adalah metode ceramah dan tanya jawab, pada kesempatan ini penulis mencoba menggunakan metode tebak kata.

Untuk menghindari salah pengertian atau salah tafsir tentang makna istilah yang digunakan dalam penelitian ini, maka perlu dijelaskan makna beberapa definisi operasional sebagai berikut : Hasil belajar pendidikan kewarganegaraan materi Peranan politik luar negeri Indonesia dalam era globalisasi. Metode Tebak kata merupakan penyampaian materi ajar dengan menggunakan kata-kata singkat dalam bentuk kartu permainan sehingga anak dapat menerima pesan pembelajaran melalui kartu itu. Untuk itu, buatlah kartu yang didalamnya mengandung berbagai pertanyaan yang membutuhkan satu karta jawaban yang dapat mewakili dari seluruh pertanyaan atau pernyaan yang ada.

Menurut Edi Purnomo (2013) metode pembeljaran tebak kata merupakan penyampaian materi ajar dengan menggunakan kata-kata singkat dalam bentuk kartu permainan sehingga anak dapat menerima pesan pembelajaran melalui kartu itu. Untuk itu, buatlah kartu yang didalamnya mengandung berbagai pertanyaan yang membutuhkan satu karta jawaban yang dapat mewakili dari seluruh pertanyaan atau pernyaan yang ada. Dengan demikian menebak kata merupakan aktivitas pembelajaran yang pertama dan utama dalam mewujudkan keberhasilan proses belajar mengajar. Melalui tebak kata, murid diarahkan untuk memahami dan mengetahui pesanpesan yang terkandung dalam amteri.

Jadi dengan mampunya murid menebak kata berarti mencerminkan kemampuan murid dalam menguasai dan memahami materi yang ada.

Langkah-langkah

Model

Pembelajaran Tebak Kata:

1. Guru mempersiapkan kartu yang akan digunakan dalam proses pembelajaran.

2. Guru menjelaskan kompetensi yang ingin dicapai atau materi pelajaran selama \pm 45 menit.

3. Guru menyusun peserta didik berdiri berpasangan didepan kelas.

4. Seorang peserta didik diberi kartu yang berukuran 10x10 $\mathrm{cm}$ yang nantinya dibacakan kepada pasanganya. Seorang peserta didik lainnya diberikan kartu dengan ukuran $5 \times 2 \mathrm{~cm}$ yang isinya tidak boleh dibaca (kertasnya dilipat) kemudian ditempelkan di dahi atau diselipkan ditelinga (dengan syarat murid yang memegang kartu yang 
berukuran 10x10 $\mathrm{cm}$ bisa melihat apa jawabannya).

5. Peserta didik yang memegang kartu $10 \times 10 \mathrm{~cm}$ membacakan kata-kata yang tertulis didalamnya sementara pasanganya menebak apa yang dimaksud dalam kartu 10x10 cm. Jawaban tepat apabila sesuai isi kartu yang berukuran $5 \times 2 \mathrm{~cm}$ tersebut.

6. Apabila jawabanya tepat (sesuai yang tertulis dikartu) maka pasangan itu boleh duduk. Bila belum tepat pada waktu yang ditetapkan, peserta didik boleh mengarahkan dengan kata-kata lain, dengan syarat tidak langsung memberikan jawabannya.

7. Pengambilan kesimpulan.

8. Penutup.

Adapun yang menjadi kelebihan dari Model Pembelajaran Tebak Kata adalah sebagai berikut:

1. Pemebelajaran yang dilakukan lebih menarik karena menggunakan media kartu, sehingga murid tidak jenuh atau bosan.

2. Dapat meningkatkan daya berpikir murid, karena murid dituntut untuk menjawab suatu kata yang membutuhkan pikiran kritis peserta didik.

3. Pembelajaran akan lebih berkesan

4. Melatih murid untuk menemukan jawaban dengan menggunakan berbagai alternatif jawaban.

5. Melibatkan seluruh anggota tubuuh dalam proses pembelajaran, seperti berdiri, duduk, dan mencari pasangan.

Tebak Kata

Kekurangan Model Pembelajaran

1. Tidak mudah bagi guru untuk membuat kartu-kartu yang menarik untuk diamati oleh anak didik.

2. Tidak mudah bagi guru untuk menyusun rangkaian kata perkata di dalam kartu sehingga membutuhkan satu kartu sebagai jawaban hasil tebakan anak didik.
3. Sering kali murid beranggapan bahwa model ini bukan untuk belajar, tetapi hanya sebagai permainan sehingga anak didik merasa ini hanya permainan belaka. Padahal model ini dilakukan dalam rangka mengikutsertakan komponen tubuh murid dalam proses pembelajaran, seperti berdiri, duduk dan mencari pasang

\section{METODE}

Prosedur penelitian tindakan kelas ini merujuk pada model Kurt Lewin yang terdiri atas empat komponen pokok penelitian kelas yakni: 1) perencanaan (planning), 2) tindakan (acting), 3) pengamatan (observing), dan 4) refleksi (reflecting) (Zainal Aqib, 2007). Juga disampaikan Suroto (2017) bahwa metode tindakan menjadi sarana untuk mencari solusi dari masalah sosial.

Analisis data dalam penelitian tindakan kelas ini menggunakan analisis kuantitatif dan kualitatif (Supardi, 2006). Terhadap perolehan hasil belajar PKN dianalisis secara kuantitatif dengan memberikan nilai pada hasil belajar murid. Data-data tersebut dianalisis mulai dari siklus satu sampai dengan siklus tuga untuk dibandingkan dengan teknik deskriptif presentase. Hasil perhitungan dikonsultasikan dengan tabel kriteria deskriptif prosentase, yang dikelompokkan dalam 3 kategori, yaitu baik, cukup, kurang. Hasil observasi dianalisis menggunakan teknik deskriptif kualitatif yang digambarkan dengan kata-kata atau kalimat, dipisah-pisahkan menurut kategori untuk memperoleh kesimpulan.

\section{HASIL}

Telah diketahui bahwa subjek penelitian berjumlah 26 murid. Pelaksanaan penelitian tindakan kelas ini dilakukan dalam 3 (tiga) siklus, yakni siklus I. Berikut disajikan paparan hasil penelitian yang terdiri atas hasil belajar PKN melalui kolaborasi model pembelajaran tebak kata 
dan hasil observasi terhadap proses pembelajaran.

\section{Siklus I}

Berdasarkan data hasil penelitian siklus I mengenai hasil belajar PKN materi pokok menjelaskan pengertian dan mengidentifikasi peranan politik luar negeri Indonesia dalam era globalisasi, melalui model pembelajaran tebak kata diperoleh data untuk ketuntasan 80 sebanyak 84,6\% tidak tuntas. Selengkapnya dapat dibaca pada tabel distribusi frekuensi bergolong sesuai dengan kategori hasil belajar.

\section{Siklus II}

Berdasarkan data hasil penelitian siklus I mengenai hasil belajar PKN materi pokok yang sama mengenai system pemerintahan, melalui model pembelajaran tebak kata diperoleh data untuk ketuntasan 80 sebanyak $15,4 \%$ tidak tuntas. dan rata-rata hasil belajar sebesar 80. Selengkapnya dapat dibaca pada tabel distribusi frekuensi bergolong sesuai dengan kategori hasil belajar menunjukkan bahwa perolehan hasil belajar melalui metode tebak kata Siklus II ketuntasan individual baru mencapai 84,6\%. Potret pembelajaran PKN sudah mencapai tujuan dari jumlah murid dalam kelas telah mencapai ketuntasan belajar individual, sehingga untuk kesempurnaan perlu dilaksanakan siklus III.

\section{Siklus III}

Berdasarkan data hasil penelitian siklus I mengenai hasil belajar PKN materi pokok yang sama namun dengan bahasan memahami system yang ada, melalui model pembelajaran tebak kata diperoleh data untuk ketuntasan 80 sebanyak 5100\%. dan rata-rata hasil belajar sebesar 85 . Selengkapnya dapat dibaca pada tabel distribusi frekuensi bergolong sesuai dengan kategori hasil belajar menunjukkan bahwa perolehan hasil belajar melalui metode tebak kata Siklus II ketuntasan individual baru mencapai $100 \%$. Potret pembelajaran PKN sudah mencapai tujuan yang diharapkan guru yang tertuang dalam indikator kinerja dari jumlah murid dalam kelas telah mencapai ketuntasan belajar individual, sehingga sudah perlu dapat diakhiri penelitian ini.

\section{PEMBAHASAN}

Penerapan metode tabak kata dapat meningkatkan hasil belajar pendidikan kewarganegaraan khususnya pada materi pemahaman terhadap Peranan politik luar negeri Indonesia dalam era globalisasi dengan capaian nilai KKM dan sikap perilaku murid sebagai warganegara.

Hasil observasi pada semua siklus diperoleh gambaran tentang sikap para murid dalam mengikuti pelajaran sudah memberikan perubahan pada perilaku murid khususnya dalam menyelesaikan tugas yang diberikan, dimana murid sudah dapat dipercaya terbukti masih terlambat dan juga sudah jujur dalam menyelesaikan tugas seperti tidak mencontek namun sudah menunjukkan sikap kewarganegaraan yang siap memberikan baktinya dalam melaksanakan kebersamaan dalam lokal.

Dari sudut guru kemampuan mengajar guru sudah baik, ada peningkatan yang signifikan. Guru sudah baik dalam mengelola ruang, fasilitas, strategi, interaksi dengan murid, dan evaluasi dengan baik juga untuk pengelolaan waktu sudah dapat terlaksana dengan efektif, karena guru sudah terbiasa menggunakan model pembelajaran. Kesan umum guru dalam mengajar sudah luwes dan sudah peka dengan kondisi murid.

Hal ini juga sejalan dengan apa yang dikatakan oleh Wahyun, T., Marli, S., \& Sabri, T. (2014) bahwa adanya peningkatan motivasi belajar siswa dengan menggunakan model kooperatif teknik tebak kata di Sekolah Dasar.

\section{KESIMPULAN}

Berdasarkan uraian di atas, maka dapat ditarik kesimpulan bahwa melalui penelitian tindakan kelas, akan menerapkan metode tebak kata untuk menambah peningkatan pengetahuan beserta dengan pemahamannya dalam melihat materi pelajaran peranan Indonesia di era globalisasi. Kepada siswa SD Negeri 025 
khususnya kelas VI diterapkan metode ini dan data yang terkumpul melalui observasi dan kuesioner dianalisis secara deskriptif. Hasil penelitian menunjukkan bahwa penerapan metode tebak kata yang diterapkan kepada murid SD kelas VI mampu meningkatkan pengetahuan dan pemahamannya tentang peranan bangsa Indonesia di era globalisasi.

\section{DAFTAR RUJUKAN}

Aqib, Zainal. (2007). Penelitian Tindakan Kelas untuk Guru. Bandung: Yrama Widya.

Edi Purnomo, 2013, Model Pembelajaran Tebak Kata, etc, Jakarta.

Moh. Uzer Usman. 2005. Menjadi Guru Profesional. Bandung : Remaja. Rosdakarya.

Suroto, B., Novita, N., Pailis, E. A., Waldelmi, I., \& Fatkhurahman, F. (2017). Metode Penelitian Tindakan Solusi Bagi Masalah Sosial. Jurnal Diklat Review, 1(1), 25-28.

Wahyun, T., Marli, S., \& Sabri, T. (2014). Peningkatan Motivasi Belajar Siswa dengan Menggunakan Model Kooperatif Teknik Tebak Kata di Sekolah Dasar. Jurnal Pendidikan dan Pembelajaran, 3(11). 